\title{
Upaya Meningkatkan Kinerja Guru Dalam Pembelajaran Di Kelas Melalui Supervisi Edukatif Kolaboratif Pada MTS Al-Huda Kota Gorontalo
}

\author{
Anis Domili \\ Kepala MTS Al-Huda Kota Gorontalo \\ anisdomili@gmail.com
}

Received: 04 March 2021; Revised: 26 April 2021; Accepted: 28 July 2021

DOI: http://dx.doi.org/10.37905/aksara.7.3.1143-1148.2021

\begin{abstract}
ABSTRAK:
Penelitian Tindakan Sekolah ini dilakukan di MTS Al-Huda Kota Gorontalo. Jenis tindakan dalam penelitian ini adalah berupa tindakan nyata yaitu membimbing guru dalam melaksanakan kegiatan pembelajaran melalui supervisi Akademik. Penelitian dilakukan pada semester I, tepatnya pada bulan Juli - Nopember 2020.

Hasil penelitian menunjukkan bahwa kinerja guru meningkat setelah dilakukan tindakan yang berupa supervisi edukatif kolaboratif secara periodik dari siklus I ke siklus II. Peningkatan tersebut meliputi peningkatan dalam menyusun rencana pembelajaran, melaksanakan pembelajaran, menilai prestasi belajar, melaksanakan tindak lanjut penilaian prestasi belajar siswa Berdasarkan hasil supervisi edukatif siklus I dan siklus II kinerja guru meningkat, yakni siklus I Kinerja guru dalam menyusun rencana pembelajaran siklus I mencapai $71,98 \%$ sedangkan siklus II 92,44 \%. Kinerja guru dalam melaksanakan pembelajaran siklus I mencapai 75,49\% sedangkan siklus II mencapai 93,81\%. Kinerja guru dalam menilai prestasi belajar siklus I mencapai 81,3\% sedangkan siklus II $90,56 \%$. Kinerja guru dalam melaksanakan tindak lanjut penilaian prestasi belajar siswa pada siklus I mencapai $54 \%$ sedangkan siklus II 59,76\%. Dengan demikian tindakan siklus II rata-rata sudah di atas $83 \%$.

Berdasarkan hasil penelitian tindakan tersebut dapat disimpulkan bahwa kinerja guru meningkat dalam menyusun rencana pembelajaran, melaksanakan pembelajaran, menilai prestasi belajar, melaksanakan tindak lanjut penilaian prestasi belajar siswa. Untuk itu, peneliti menyarankan agar supervisi edukatif di sekolah-sekolah melaksanakan supervisi edukatif kolaboratif secara periodik.
\end{abstract}

Kata kunci : Kinerja guru, supervisi, edukatif

\section{PENDAHULUAN}

Dalam rangka meningkatkan mutu pendidikan di Indonesia, pemerintah telah menetapkan Undang-Undang Sistem Pendidikan. Undang-Undang tersebut memuat dua puluh dua bab, tujuh puluh tujuh pasal dan penjelasannya. Undang-undang Sistem Pendidikan (2003:37) menjelaskan bahwa setiap pembaruhan sistem pendidikan nasional untuk memperbarui visi, misi dan strategi pembangunan pendidikan nasional 
Jika mencermati visi pendidikan tersebut, semuanya mengarah pada mutu pendidikan yang akhirnya dapat meningkatkan hasil belajar peserta didik. Mutu pendidikan ternyata dipengaruhi oleh banyak komponen. Menurut Syamsuddin (2005:66) ada tiga komponen utama yang saling berkaitan dan memiliki kedudukan strategis dalam kegiatan belajar mengajar. Ketiga komponen tersebut adalah kurikulum, guru, dan pembelajar (siswa). Ketiga komponen itu, guru menduduki posisi sentral sebab peranannya sangat menentukan. Dalam pembelajaran seorang guru harus mampu menerjemahkan nilai-nilai yang terdapat dalam kurikulum secara optimal. Walaupun sistem pembelajaran sekarang sudah tidak theacher center lagi, namun seorang guru tetap memegang peranan yang penting dalam membimbing siswa. Bahkan berdasarkan seorang guru harus mempunyai pengetahuan yang memadai baik di bidang akademik maupun pedagogik. Menurut Djazuli (1886:2) seorang guru dituntut memiliki wawasan yang berhubungan dengan mata pelajaran yang diajarkannya dan wawasan yang berhubungan kependidikan untuk menyampaikan isi pengajaran kepada siswa. Kedua wawasan tersebut merupakan satu kesatuan yang tidak dapat dipisahkan.

Seorang guru harus selalu meningkatkan kemampuan profesionalnya, pengetahuan, sikap dan keterampilannya secara terus-menerus sesuai perkembangan ilmu pengetahuan dan teknologi termasuk paradigma baru pendidikan. Menurut Dirjen Pendidikan Dasar dan Menengah Departeman Pendidikan Nasional (2004:2) seorang guru harus memenuhi tiga standar kompetensi, di antaranya: (1) Kompetensi Pengelolaan Pembelajaran dan Wawasan Kependidikan, (2) Kompetensi Akademik/Vokasional sesuai materi pembelajaran, (3) Pengembangan Profesi. Ketiga kompetensi tersebut bertujuan agar guru bermutu, menjadikan pembelajaran bermutu juga, yang akhirnya meningkatkan mutu pendidikan Indonesia.

Untuk mencapai tiga kompetensi tersebut, sekolah harus melaksanakan pembinaan terhadap guru baik melalui workshop, PKG, diskusi dan supervisi edukatif. Hal itu harus dilakukan secara periodik agar kinerja dan wawasan guru bertambah sebab berdasarkan diskusi yang dilakukan guru di MTS Al-Huda Kota Gorontalo, rendahnya kinerja dan wawasan guru diakibatkan (1) rendahnya kesadaran guru untuk belajar, (2) kurangnya kesempatan guru mengikuti pelatihan, baik secara regional maupun nasional, (3) kurang efektifnya PKG, (4) supervisi pendidikan yang bertujuan memperbaiki proses pembelajaran cenderung menitikberatkan pada aspek administrasi. Untuk memperbaiki kinerja dan wawasan guru dalam pembelajaran di MTS Al-Huda Kota Gorontalo, sekolah melaksanakan penelitian tindakan yang berkaitan dengan permasalahan di atas

\section{METODE PENELITIAN}

Penelitian ini dilaksanakan di MTS Al-Huda Kota Gorontalo pada tahun pelajaran 2020/2021. Pada tahun itu banyak hasil penelitian yang kurang mengarah pada peningkatan mutu pendidikan. Waktu penelitian adalah pada tahun pelajaran 2020/2021. Selama penelitian tersebut peneliti mengumpulkan data awal, menyusun program supervisi, pelaksanaan supervisi, analisis, dan tindak lanjut.

Teknik pengumpulan data pada penelitian ini terdiri atas empat kegiatan pokok yakni pengumpulan data awal, data hasil analisis setiap akhir siklus, serta tanggapan lain dari guru terhadap pelaksanaan supervisi edukatif model kolaboratif. 
Data yang telah dikumpulkan dianalisis dengan menggunakan analisis kualitatif dan kuantitatif. Analisis kualitatif digunakan untuk menjelaskan perubahan perilaku guru dalam pembelajaran dan perilaku Peneliti dalam melaksanakan supervisi guru. Adapun analisis kuantitatif digunakan untuk mengetahui keberhasilan guru dan siswa berdasarkan standar kompetensi guru yang telah ditetapkan oleh Depdiknas.

Indikator keberhasilan yang dicapai oleh peneliti dalam penelitian ini ialah apabila persentasi rata - rata keberhasilan dari keseluruhan guru kelas meningkat. Sedangkan tolak ukur nilai keberhasilan dari seorang guru sebesar $\geq 75$. Aspek - aspek kinerja guru yang ditujukan sebagai indikator keberhasilan, diantaranya : kinerja guru dalam menyusun rencana pembelajaran, kinerja guru dalam melaksanakan pembelajaran, kinerja guru dalam menilai prestasi belajar siswa, kinerja guru dalam melaksanakan tindak lanjut hasil penilaian prestasi belajar siswa. Dengan meningkatnya kinerja guru maka dapat berakibat terjadinya pembelajaran efektif yang mampu memotivasi belajar siswa dengan meningkatnya hasil belajar terutama nilai ujian semester.

\section{PEMBAHASAN}

Pembahasan didasarkan pada teori-teori yang sudah ada, baik berdasarkan pada referensi mapun dari ucapan ahli di bidang penelitian ini. Adapun pembahasan hasil penelitian ini sebagai berikut.

Temuan pertama, kinerja guru meningkat dalam membuat perencanaan pembelajaran. Hal ini terjadi karena adanya kerja sama antara guru kelas yang satu dengan lainnya serta diberi pengarahan oleh peneliti. Langkah-langkah yang dapat meningkatkan kinerja guru dalam membuat persiapan pembelajaran adalah: (1) Peneliti memberikan format supervisi dan jadwal supervisi pada awal tahun pelajaran atau awal semester. Pelaksanaan supervisi tidak hanya dilakukan sekali, (2) Peneliti selalu menanyakan perkembangan pembuatan perangkat pembelajaran (mengingatkan betapa pentingnya perangkat pembelajaran), (3) satu minggu sebelum pelaksanaan supervisi perangkat pembelajaran, Peneliti menanyakan format penilaian, jika format yang diberikan pada awal tahun pelajaran tersebut hilang, maka guru yang bersangkutan disuruh memfotokopi arsip sekolah. Jika di sekolah masih banyak format seperti itu maka guru tersebut diberi kembali. Bersamaan dengan memberi/menanyakan format, Peneliti meminta pengumpulan perangkat pembelajaran yang sudah dibuatnya untuk untuk diteliti kelebihan dan kekurangannya, (4) Peneliti memberikan catatan-catatan khusus pada lembaran untuk diberikan kepada guru yang akan disupervisi tersebut. (5) Peneliti dalam menilai perangkat pembelajaran penuh perhatian dan tidak mencerminkan sebagai penilai. Peneliti bertindak sebagai kolaborasi. Peneliti membimbing, mengarahkan guru yang belum bisa, tetapi Peneliti juga menerima argumen guru yang positif. Dengan adanya itu, terciptalah hubungan yang akrap antara guru dan Peneliti. Tentu saja ini akan membawa nilai positif dalam pelaksanaan pembelajaran.

Temuan kedua, kinerja guru meningkat dalam melaksanakan pembelajaran. Dalam penelitian tindakan ini ternyata dari 6 guru hampir semuanya mampu melaksanakan pembelajaran dengan baik. Hal ini terbukti dari hasil supervisi. Langkahlangkah yang dilakukan untuk meningkatkan pelaksanaan pembelajaran berdasarkan penelitian tindakan ini adalah: (1) Peneliti yang mengamati guru mengajar tidak sebagai penilai tetapi sebagai rekan bekerja yang siap membantu guru tersebut, (2) Selama 
pelaksaaan supervisi di di kelas guru tidak menganggap Peneliti sebagai penilai karena sebelum pelaksanaan supervisi guru dan Peneliti telah berdiskusi permasalahanpermasalahan yang ada dalam pembelajaran tersebut, (3) Peneliti mencatat semua peristiwa yang terjadi di dalam pembelajaran baik yang positif maupun yang negatif, (4) Peneliti selalu memberi contoh pembelajaran yang berorientasi pada Modern Learning. (5) Jika ada guru yang pembelajarannya kurang jelas tujuan, penyajian, umpan balik, Peneliti memberikan contoh bagaimana menjelaskan tujuan, menyajikan, memberi umpan balik kepada guru tersebut, (6) Setelah guru diberi contoh pembelajaran modern, Peneliti setiap dua atau tiga minggu mengunjungi atau mengikuti guru tersebut dalam proses pembelajaran.

Temuan ketiga, kinerja guru meningkat dalam menilai prestasi belajar siswa. Pada penelitian tindakan yang dilakukan di MTS Al-Huda Kota Gorontalo ini ternyata pelaksanaan supervisi edukatif kolaboratif secara periodik memberikan dampak positif terhadap guru dalam menyusun soal/perangkat penilaian, melaksanakan, memeriksa, menilai, mengolah, menganalisis, menyimpulkan, menyusun laporan dan memperbaiki soal. Sebelum diadakan supervisi edukatif secara kolaboratif, guru banyak yang mengalami kesulitan dalam melaksankan penilaian. Langkah-langkah yang dilakukan dalam supervisi edukatif kolaboratif secara periodik yang dapat meningkatkan kinerja guru adalah: (1) Peneliti berdiskusi dengan guru dalam pembuatan perangkat penilaian sebelum dilaksanakan supervisi, (2) Guru melaksanakan penilaian sesuai dengan aturan yang telah ditetapkan bersama Peneliti yang sebagai kolaboratif dalam pembelajaran, (3) Guru membuat kriteria penilaian yang berkaitan dengan penskoran, pembobotan, dan pengolahan nilai, yang sebelum pelaksanaan supervisi didiskusikan dengan peneliti, (4) Guru menganalisis hasil penilaian dan melaorkannya kepada urusan kurikulum.

Temuan keempat, Kinerja guru meningkat dalam melaksanakan tindak lanjut hasil penilaian prestasi belajar peserta didik. Langkah-langkah yang dapat meningkatkan kinerja guru dalam supervisi edukatif kolaboratif adalah: (1) Peneliti dan guru bersamasama membuat program tindak lanjut hasil penilaian, (2) Peneliti memberi contoh pelaksanaan tindak lanjut, yang akhirnya dilanjutkan oleh guru dalam pelaksanaan yang sebenarnya, (3) Peneliti mengajak diskusi pada guru yang telah membuat, melaksanakan, dan menganalis program tindak lanjut.

Temuan kelima, Kinerja guru meningkat dalam menyusun program pembelajaran, melaksanakan pembelajaran, menilai prestasi belajar, dan melaksanakan tindak lanjut hasil prestasi belajar siswa.

\section{PENUTUP}

Berdasarkan temuan hasil penelitian ada empat hal yang dikemukakan dalam penelitian tindakan ini, yakni simpulan tentang: (1) Peningkatan kinerja guru dalam menyusun rencana pembelajaran, (2) Peningkatan kinerja guru dalam melaksanakan pembelajaran, (3) Peningkatan kinerja guru dalam menilai prestasi belajar, (4) Peningkatan kinerja guru dalam melaksanakan tindak lanjut hasil penilaian prestasi belajar siswa. Peningkatan kinerja guru baik rencana pembelajaran, pelaksanaan pembelajaran, penilaian hasil belajar, dan pelaksanaan tindak lanjut hasil penilaian siswa ternyata mempengaruhi hasil ujian siswa tahun 2020.

Berdasarkan temuan-temuan penelitian tindakan ini, ada beberapa saran yang perlu disampaikan kepada pengambil kebijakan sekolah, di antaranya adalah. 1) Supervisi 
terhadap semua guru perlu dilakukan secara periodik dan ditetapkan pada awal tahun pelajaran (pada saat pembagian tugas). 2) Supervisi edukatif ternyata membawa peningkatan kinerja guru dan hasil belajar siswa jika dilaksanakan secara kolaboratif. 3) Supervisi edukatif kolaboratif akan bermakna jika Penelitinya adalah teman sejawat yang sudah mampu pada mata pelajaran yang bersangkutan. 4) Perlu memberi kesempatan pada guru-guru yang dianggap sudah mampu mensupervisi guru lain.

\section{DAFTAR PUSTAKA}

Permendiknas Nomor: 16 Tahun 2007 tentang Standar Kualifikasi Akademik dan Kompetensi Guru.

Fakri, 2019. Teknis Penulisan Laporan PTK dan PTS Aceh Timur: Dinas Pendidikan

Hamalik, Uemar. 2004 . Pendidikan Guru Berdasarkan Pendekatan Kompetensi. Jakarta: Dirjen Ketenagaan Dikti.

Nana Sudjana, Prof., Dr. 2009. Kompetensi Pengawas sekolah. Jakarta: Binamitra Publishing

Nana Syaodih Sukmadinata, 2006. Metode Penelitian Pendidikan. Bandung: Remaja Rosdakarya.

Suryosubroto, 1997. Metode dan pendekatan Belajar Mengajar. Jakarta: Binamitra

Suhardjono, 2008. Penelitian Tindakan Kelas dan Penelitian Tindakan sekolah. Malang: Cakrawala Indonesia bekerjasama dengan LP3UM 
AKSARA: Jurnal Ilmu Pendidikan Nonformal

P-ISSN 2407-8018 E-ISSN 2721-7310 DOI prefix $\underline{10.37905}$

Volume 07, (03) September 2021

http://ejurnal.pps.ung.ac.id/index.php/Aksara

1148 AKSARA: Jurnal Ilmu Pendidikan Nonformal 